\title{
Marktführende Plattform für Praxisanbieter \& Praxissucher
}

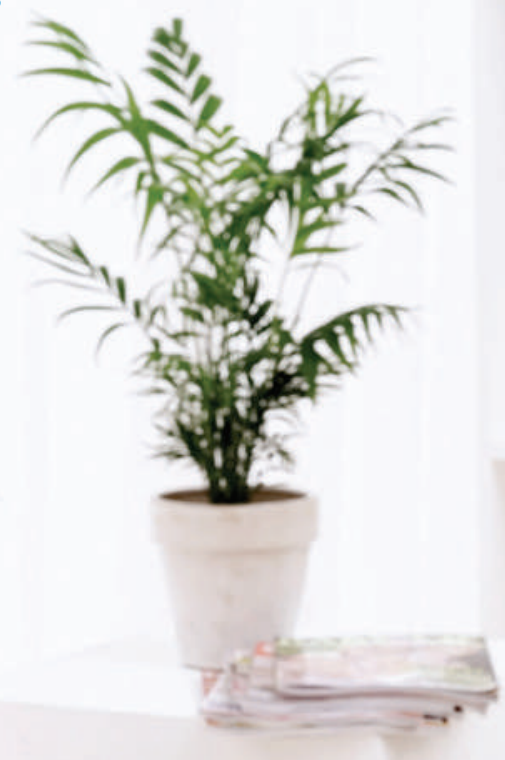
Ф̧ FMH SERVICES

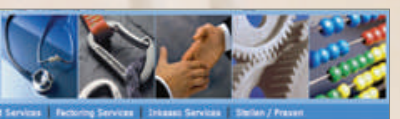

Schweizerische Ärztezeitung
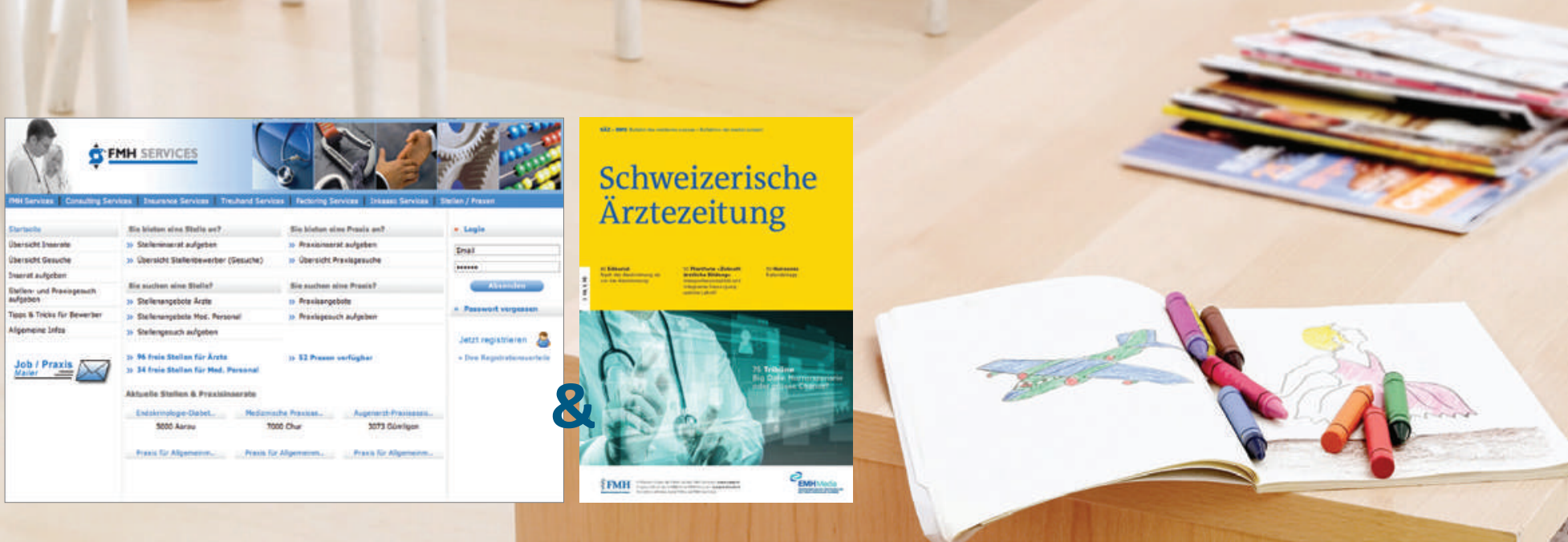

\section{WWW.FMHPRAX.CH}

\section{Für Praxisanbieter}

- Einfache Erfassung, Änderung und Verwaltung von Anzeigen

- Attraktiver Kombipreis für Web (www.fmhprax.ch) und Print (Schweizerische Ärztezeitung)

- Chiffreangebot

- Kostenloses Hochladen von Bildern für die perfekte Praxispräsentation

Für Praxissucher

- Einfache Erfassung, Änderung und Verwaltung von Praxisgesuchen

- Attraktiver Kombipreis für Web (www.fmhprax.ch) und Print (Schweizerische Ärztezeitung)

- Chiffreangebot

- Neue Praxisangebote kostenlos per E-Mail (Praxis Mailer)

\section{FMH CONSULTING SERVICES}

FMH Consulting Services AG Burghöhe 1, 6208 Oberkirch Tel. 0419250077 - Fax 0419210586 mail@fmhjob.ch - www.fmhservices.ch 